\title{
PENGARUH PENDIDIKAN KESEHATAN TENTANG PHBS DENGAN MEDIA PERMAINAN ULAR TANGGA DAN CERAMAH TERHADAP PENGETAHUAN SISWA SD NEGERI LIMPAKUWUS KABUPATEN BANYUMAS TAHUN 2017
}

\author{
Annisa Nurhidayati ${ }^{*}$, Nur Hilal ${ }^{* *}$ \\ Jurusan Kesehatan Lingkungan, Politeknik Kesehatan Kemenkes Semarang, \\ Jl.Raya Baturaden KM 12 Purwokerto, Indonesia
}

\begin{abstract}
Abstrak
Menurut data PHBS tatanan Institusi Pendidikan Sekolah Dasar Tahun 2016 dari Puskesmas Sumbang 1 dan Puskesmas Sumbang 2, jumlah nilai terendah terdapat di SDN Limpakuwus. Berdasarkan kuisioner yang didapat Puskesmas Sumbang 2 mengenai data PHBS di SDN Limpakuwus, tidak terdapat dokter kecil atau kader kesehatan, terdapat siswa yang merokok, tidak terdapat gerakan PSN dengan 3M, siswa tidak menjadi anggota Dana Sehat/JPK, serta tidak terdapat warung sekolah/kantin yang sehat. Tujuan penelitian ini adalah mengetahui pengaruh pendidikan kesehatan tentang PHBS dengan media permainan ular tangga dan ceramah terhadap peningkatan pengetahuan siswa SD Negeri Limpakuwus Kecamatan Sumbang Kabupaten Banyumas Tahun 2017. Jenis penelitian ini adalah pra eksperimen. Populasi dalam penelitian ini adalah siswa sekolah dasar SDN 1 Limpakuwus dan SDN 2 Limpakuwus Kabupaten Banyumas. Sampel dalam penelitian berjumlah 40 siswa, dengan 20 siswa kelas IV SDN 1 Limpakuwus yang mendapatkan pendidikan kesehatan dengan media permainan ular tangga serta 20 siswa kelas IV SDN 2 Limpakuwus yang mendapatkan pendidikan kesehatan dengan ceramah. Hasil penelitian menunjukkan bahwa berdasarkan hasil uji t berpasangan pada kelompok perlakuan 1 dengan menggunakan media ular tangga didapatkan hasil nilai p 0,000<0,005 yang berarti terdapat perbedaan bermakna antara nilai pretest dan posttest pada kelompok perlakuan 1. Sedangkan pada kelompok perlakuan 2 dengan ceramah didapatkan hasil bahwa nilai p 0,513 > 0,005 yang berarti tidak ada perbedaan bermakna antara nilai pretest dan posttest pada kelompok perlakuan 2. Hasil uji t tidak berpasangan antara kelompok media ular tangga dan ceramah didapatkan hasil nilai p 0,000 < 0,005. Artinya bahwa terdapat perbedaan yang bermakna antara kelompok perlakuan.Kesimpulan dalam penelitian ini adalah terdapat pengaruh pendidikan kesehatan tentang PHBS dengan media permainan ular tangga, namun tidak terdapat pengaruh pendidikan kesehatan tentang PHBS dengan cermah..Peneliti menyarankan kepada peneliti selanjutnya untuk dapat mengontrol variabel pengganggu secara ketat yang meliputi waktu penelitian yang sama dan jarak waktu pretest-posttest yang sama.
\end{abstract}

Kata kunci: Pendidikan Kesehatan; ular tangga;

\begin{abstract}
Based on behavior clean and healthy lifestyle (PHBS) data of educational elementary school institutions level year of 2016 from Puskesmas Sumbang 1 and Puskesmas Sumbang 2, the lowest score was in SDN Limpakuwus. Based on questioner from Puskesmas Sumbang 2 about clean and healthy lifestyle behavior (PHBS) data in SDN Limpakuwus, there are no little doctor or health cadre, there are students who smoke, did not conduct mosquito breeding place eradication with 3M, student did not became member of health insurance, and did not have school food stalls/ health cafeteria. The purpose of this study was determined the effect of health education about clean and healthy lifestyle behavior (PHBS) with snake and ladder game media and lecturing on the students knowledge in SD Negeri Limpakuwus Banyumas Regency year of 2017. The research method used was pre-experimental. The research population wereSDN 1 Limpakuwus and SDN 2 Limpakuwus students Banyumas Regency. The research sample in this study was 40 students, 20 SDN 1 Limpakuwus fourth grade students receiving health education through snake and ladder game media and 20 SDN 2 Limpakuwus fourth grade students receiving health education through lecturing. The paired t-test analysis result shows that in the group who receiving health education through snake and ladder game media obtained p-value $0.000<0.005$ that's mean there are significant differences between pretest score and posttest score. Meanwhile the paired t-test for group which receiving health education through lecturing obtainedp-value $0.513>0.005$ that's mean there was no significant differences between pretest score and posttest score. The independent t-test result between snake and ladder group media and lecturing obtainedp-value $0.000<0,005$ that's means that there are significant differences between the two groups. The conclusion drawn in thise research was there are significant effect of clean and healthy lifestyle behavior (PHBS) health education through snake and ladder game media, but there was no significant effect of clean and healthy lifestyle behavior (PHBS) health education about through lecturing. The proposed suggestion forfuture researchers to control confounding variables including conducting the pretest-posttest measurement in the same time.
\end{abstract}

Keywords: Heelth education; Snack and ladder

\footnotetext{
*) nurhidayatiannisa97@gmail.com
} 


\section{Pendahuluan}

Perilaku Hidup Bersih dan Sehat (PHBS) merupakan salah satu perilaku yang berkaitan dengan upaya atau kegiatan seseorang untuk meningkatkan kesehatan berdasarkan kesadarannya, sehingga mampu mencegah penyakit serta berperan aktif dalam mewujudkan lingkungan sehat dengan cara olahraga teratur, tidak merokok, istirahat yang cukup dan gaya hidup yang positif (Notoatmodjo,2007).

Permasalahan kesehatan pada anak banyak ditemukan pada periode anak sekolah, hal ini sangat menentukan kualitas anak dikemudian hari. Masalah kesehatan tersebut meliputi perilaku hidup bersih dan sehat, gangguan perkembangan, gangguan perilaku dan gangguan belajar. Kemudian secara epidemiologis masalah kesehatan anak terkait dengan penyebaran penyakit berbasis lingkungan dikalangan anak sekolah, resiko gangguan kesehatan pada anak akibat pencemaran lingkungan dari berbagai proses kegiatan pembangunan di Indoensia masih tinggi atau meningkat dan masalah yang harus diperhatikan adalah membentuk perilaku pada anak usia SD biasanya berkaitan dengan kebersihan perorangan dan lingkungan seperti gosok gigi yang baik dan benar, kebiasaan mencuci tangan pakai sabun dan kebersihan diri (Luluq,2014).

Menurut Menteri Kesehatan RI, Endang Rahayu Sedyaningsih bahwa anak usia sekolah mudah dimotivasi dan ditingkatkan kompetensinya meliputi aspek pengetahuan, sikap dan perilaku pada bidang kesehatan, sehingga dapat berpotensi sebagai agen perubahan (agent of change). Diharapkan dengan pendidikan kesehatan anak usia sekolah memiliki pengetahuan yang memadai sehingga terbiasa menerapkan perilaku hidup bersih dan sehat dalam kehidupan-kehidupan sehari-hari (Pudjiati,2014).

Salah satu program kesehatan adalah upaya promosi kesehatan di sekolah melalui program PHBS di Sekolah. PHBS di Sekolah adalah sekumpulan perilaku yang dipraktikan oleh peserta didik, guru dan masyarakat lingkungan sekolah atas dasar kesadaran sebagai hasil pembelajaran, sehingga secara mandiri mampu mencegah penyakit, meningkatkan kesehatannya, serta berperan aktif dalam mewujudkan lingkungan sehat. Secara nasional ada 8 indikator yaitu sebagai ukuran untuk menilai PHBS di sekolah yaitu:1) mencuci tangan dengan air yang mengalir dan menggunakan sabun, 2) mengkonsumsi jajanan sehat di kantin sekolah, 3) menggunakan jamban yang bersih dan sehat, 4) olahraga yang teratur dan terukur, 5) memberantas jentik nyamuk, 6) tidak merokok di sekolah, 7) menimbang berat badan dan mengukur tinggi badan setiap 6 bulan, 8) dan membuang sampah pada tempatnya

Hasil capaian menurut kabupaten/kota di Jawa Tengah yaitu dari 35 kota pada tahun 2015, presentase rumah tangga berperilaku hidup bersih (PHBS) terendah yaitu Kab Brebes sebesar 55,89\%; Kab Kendal 59,87\%; Kab Kudus 62,28\%; Kab Semarang 64,42\%; dan Kab Magelang 66,43\%. Sedangkan untuk Kab Banyumas memperoleh presentase sebesar $79,73 \%$, ini menunjukkan bahwa Kab Banyumas menduduki proporsi paling tinggi dari beberapa kota lain di Jawa Tengah, tetapi tidak bisa dipungkiri bahwa untuk PHBS di Sekolah masih memerlukan perhatian khusus. Hal ini dikarenakan anak-anak dan remaja pada zaman sekarang masih acuh terhadap kebersihan dan kesehatan pribadi dan juga lingkungan sekitar (Kemenkes,2013).

Berdasarkan data Profil Kesehatan Kab Banyumas untuk presentase terendah rumah tangga berperilaku bersih dan sehat menurut Puskesmas Kabupaten/Kota Banyumas Tahun 2015 yaitu Puskesmas Sumbang II 60,6\%; Puskesmas Karanglewas 61\%; Puskesmas Ajibarang II 62,6\%; Puskesmas Purwokerto Selatan 63,8\%; dan Puskesmas Sokaraja II $65,4 \%$. Hal ini menunjukkan bahwa di daerah cakupan kerja Puskesmas Sumbang II dalam hal PHBS masih tergolong rendah.

Menurut data PHBS tatanan Institusi Pendidikan Sekolah Dasar Tahun 2016 dari Puskesmas Sumbang 1 dan Puskesmas Sumbang 2, jumlah nilai terendah terdapat di SDN 1 Limpakuwus. Berdasarkan kuisioner yang didapat Puskesmas Sumbang 2 mengenai data PHBS di SDN Limpakuwus, tidak terdapat dokter kecil atau kader kesehatan, terdapat siswa yang merokok, tidak terdapat gerakan PSN dengan 3M, siswa tidak menjadi anggota Dana Sehat/JPK, serta tidak terdapat warung sekolah/kantin yang sehat. Hasil observasi dan wawancara terhadap 20 siswa di SDN 1 Limpakuwus dan SDN 2 Limpakuwus menunjukkan bahwa 14 siswa masih mempunyai kebiasaan tidak mencuci tangan sebelum dan sesudah makan, masih kurangnya pengetahuan tentang cara cuci tangan yang baik dan benar, tidak menimbang berat badan dan mengukur tinggi badan setiap bulan, tidak adanya kegiatan pemberantasan jentik nyamuk dan tidak adanya kantin sekolah yang sehat.

Menurut Indah Rahmawati (2009:2), salah satu media yang dapat digunakan dalam proses kegiatan belajar mengajar adalah media permainan. Alat permainan edukatif adalah serangkaian alat yang digunakan anak, orang tua maupun guru dalam meningkatkan fungsi intelegensi, emosi dan spritual anak, sehingga muncul kecerdasan yang dengannya seluruh potensi yang dimiliki anak dapat melejit (Andang Ismail, 2009). Menurut Andang Ismail (2009:148), syarat alat permainan edukatif adalah : 1) Awet (tahan lama), 2) Sesuai kebutuhan, 3) tidak membahayakan anak, 4) mendorong anak untuk bermain bersama, 5) terbuat dari bahan yang murah dan mudah didapat.

Menurut Charina Amelia (2010), salah satu cara belajar yang efektif yaitu: membuat permainan misalnya, permainan ular tangga yang berisi beberapa pertanyaan. Apabila pemain tidak bisa menjawab pertanyaan tersebut maka harus kembali ke garis awal. Permainan ular tangga mempunyai kelebihan sebagai media belajar, yaitu: terdapatnya kuisioner yang 
diharapkan respons responden dapat meningkatkan pengetahuannya, menimbulkan kerja sama untuk memecahkan jawaban kuisioner tersebut dan meningkatkan partisipasi aktif dari responden untuk belajar.

Dengan memperhatikan uraian diatas, maka judul yang diambil oleh penulis dalam penelitian ini adalah "Pengaruh Pendidikan Kesehatan tentang PHBS dengan Media Permainan Ular Tanggaterhadap Peningkatan Pengetahuan Siswa di SD Negeri Limpakuwus Kabupaten BanyumasTahun 2017”, dengan harapan dapat meningkatkan pengetahuan siswa tentang pentingnya berperilaku hidup bersih dan sehat (PHBS).

\section{Bahan dan Metode.}

Penelitian ini menggunakan desain pra ekspreimen dengan sampel sebanyak 20 siswa kelas IV SD Negeri Limpakuwus 1 sebagai kelompok perlakuan 1 menggunakan media ular tangga dan siswa kelas IV SD Negeri Limpakuwus 2 sebagai kelompok perlakuan 2 menggunakan pendidikan kesehatan dengan ceramah yang berjumlah 20 siswa. Variabel yang diteliti adalah tingkat pengetahuan pada kelompok media ular tangga dan ceramah berdasarkan nilai pre-test dan nilai post-test. Analisis data yang digunakan yaitu univariate dan bivariate. Analisis univariate untuk mengetahui distribusi dan presentase dari tiap-tiap variabel penelitian yaitu usia siswa, jenis kelamin dan skor nilai pengetahuan siswa tentang PHBS baik pretest maupun posttest pada kelompok perlakuan 1 dan kelompok perlakuan 2. Analisis bivariate untuk menganalisis secara statistik dengan uji $\mathrm{t}$ berpasangan dan uji t tidak berpasangan. Uji $\mathrm{t}$ berpasangan untuk menganalisis pengaruh pendidikan kesehatan tentang PHBS antara nilai pretest dan posttest dengan media permainan ular tangga dan ceramah dan uji t tidak berpasangan untuk mengetahui perbedaan pengetahuan tentang PHBS antara media permainan ular tangga dan ceramah pada siswa kelas IV SDN 1 Limpakuwus dan SDN 2 Limpakuwus.

\section{Hasil dan Pembahasan.}

a. Data Umum.

1) Gambaran Lokasi Penelitian.

Lokasi penelitian ini berada di dua sekolah, yaitu Sekolah Dasar Negeri 1 Limpakuwus dan Sekolah Dasar Negeri 2 Limpakuwus. Kedua sekolah tersebut berada di satu kelurahan, yaitu Kelurahan Limpakuwus, Kecamatan Sumbang, Kabupaten Banyumas.

2) Karakteristik Responden.

a) Distribusi Responden Menurut Umur.

\begin{tabular}{|c|c|c|c|c|c|c|c|}
\hline \multirow{3}{*}{ No } & \multirow{3}{*}{$\begin{array}{l}\text { Umur } \\
\text { (tahun) }\end{array}$} & \multicolumn{4}{|c|}{ Kelompok } & \multirow{3}{*}{ Jumlah } & \multirow{3}{*}{ Persen } \\
\hline & & \multicolumn{2}{|c|}{ Perlakuan 1} & \multicolumn{2}{|c|}{ Perlakuan 2} & & \\
\hline & & Jumlah & Persen & Jumlah & Persen & & \\
\hline 1 & 9 & 1 & $5 \%$ & 7 & $35 \%$ & 8 & $28 \%$ \\
\hline 2 & 10 & 14 & $70 \%$ & 12 & $60 \%$ & 26 & $65 \%$ \\
\hline 3 & 11 & 5 & $25 \%$ & 1 & $5 \%$ & 6 & $30 \%$ \\
\hline
\end{tabular}

Berdasarkan tabel distribusi responden menurut umur tersebut, diketahui bahwa pada kelompok perlakuan 1 terdapat 1 (5\%) responden berumur 9 tahun, 14 (70\%) responden berumur 10 tahun, dan 5 (25\%) responden berumur 11 tahun. Sedangkan pada kelompok perlakuan 2 sebanyak 7 (35\%) responden berumur 9 tahun, 12 (60\%) responden berumur 10 tahun, $1(5 \%)$ responden berumur 11 tahun.

b) Distribusi Responden Menurut Jenis Kelamin.

\begin{tabular}{cccccccc}
\hline \multirow{2}{*}{ No } & \multirow{2}{*}{\begin{tabular}{c} 
Jenis \\
\cline { 3 - 6 }
\end{tabular}} & Kelamin & \multicolumn{6}{c}{ Perlakuan 1 } & \multicolumn{2}{c}{ Perlakuan 2 } & \multirow{2}{*}{ Jumlah } & Persen \\
\cline { 3 - 6 } & Jumlah & Persen & Jumlah & Persen & & \\
\hline 1 & Laki-Laki & 7 & $35 \%$ & 7 & $35 \%$ & 14 & $35 \%$ \\
2 & Perempuan & 13 & $65 \%$ & 13 & $65 \%$ & 26 & $65 \%$ \\
\hline
\end{tabular}

Berdasarkan tabel distribusi responden menurut jenis kelamin tersebut, jumlah responden pada kelompok perlakuan 1 terdapat $7(35 \%)$ responden berjenis kelamin laki-laki, dan $13(65 \%)$ responden berjenis kelamin perempuan. Sedangkan pada kelompok perlakuan 2 terdapat $7 \quad(35 \%)$ responden berjenis kelamin laki-laki, dan 13 (65\%) responden berjenis kelamin perempuan.

b. Hasil dan Analisis.

1) Perbedaan Pengetahuan PHBS pada Kelompok Perlakuan 1.

Distribusi skor pengetahuan PHBS pada kelompok perlakuan 1 dapat digambarkan pada tabel di bawah ini. Tabel 4.7 Distribusi Skor Pengetahuan PHBS pada Kelompok Perlakuan 1 .

\begin{tabular}{cccc}
\hline Responden & SkorPretest & Skor Posttest & Selisih \\
\hline 1 & 33 & 37 & 4 \\
2 & 37 & 42 & 5 \\
3 & 34 & 38 & 4 \\
4 & 36 & 39 & 3 \\
5 & 38 & 40 & 2 \\
6 & 38 & 39 & 1 \\
7 & 27 & 38 & 11 \\
8 & 24 & 36 & 12 \\
9 & 34 & 39 & 5 \\
10 & 31 & 39 & 8 \\
11 & 37 & 40 & 3 \\
12 & 32 & 38 & 6 \\
13 & 35 & 41 & 6 \\
14 & 28 & 36 & 8 \\
15 & 39 & 40 & 1 \\
16 & 28 & 33 & 5 \\
17 & 39 & 39 & 0 \\
18 & 39 & 39 & 0 \\
19 & 38 & 39 & 1 \\
20 & 37 & 38 & 1 \\
Mean & 34,2 & 38,5 & 4,3 \\
Maksimum & 39 & 33 & 12 \\
Minimum & 24 & 42 & 0 \\
\hline & & &
\end{tabular}


Pada tabel 4.7 dapat diketahui bahwa terjadi peningkatan rata-rata (mean) skor pengetahuan sebelum dan sesudah diberi penyuluhan dengan permainan ular tangga. Peningkatan pengetahuan dapat dilihat dari rata-rata skor pretest sebesar 34,2 meningkat menjadi 38,5 pada rata-rata skor posttest. Selisih peningkatan skor pengetahuan PHBS paling tinggi sebesar 12 dan paling rendah sebesar 0 , sedangkan rata-rata skor pretest dan posttest adalah 4,3.

Untuk mengetahui apakah ada perbedaan antara skor pretest dan posttest pada kelompok perlakuan 1. ini, maka dilakukan uji $\mathrm{t}$ berpasangan dengan menggunakan SPSS. Pada uji $\mathrm{t}$ berpasangan, data dikatakan ada perbedaan antara skor sebelumnya dengan skor sesudahnya apabila skor p kurang dari 0,005. Setelah dilakukan pengujian diperoleh hasil bahwa skor $\mathrm{p}$ adalah 0,000. Hal ini menunjukkan bahwa skor p kurang dari 0,005. Maka, dapat disimpulkan bahwa perbedaan bermakna antara skor pretest dan posttest pada kelompok perlakuan 1 .

Anak sekolah dasar adalah anak yang berusia 6-12 tahun. Menurut Zulkifli (2006) menyatakan bahwa anak mempunyai sifat suka bermain. Permainan merupakan kesibukan yang dipilih sendiri tanpa ada unsur paksaan, tanpa didesak oleh rasa tanggung jawab. Anakanak suka bermain karena di dalam dirinya terdapat dorongan batin dan dorongan mengembangkan diri. Menurut Charina Amelia (2010), salah satu belajar yang efektif yaitu dengan membuat permainan. Menurut Suyatno (2009:2), ada beberapa alasan belajar dengan menggunakan permainan, yaitu:

a) Anak belajar melalui berbuat (learning by doing)

Dengan media permainan ular tangga ini, anak dapat memeragakan dan mengajarkan cara cuci tangan yang benar, sehingga anak dapat mencoba hal yang baru dan anak akan banyak memperoleh pengalaman baru, dan inilah yang disebut proses belajar.

b) Anak belajar melalui panca indera.

Dalam media permainan ular tangga ini, anak dapat belajar melalui penglihatan, pendengaran, dan perabaan. Indera penglihatan yaitu dengan gambar-gambar tentang PHBS di sekolah yang terdapat di media permainan ular tangga, indera pendengaran yaitu ketika lawan main membacakan jawaban dengan menggunakan kartu jawaban atas pertanyaan yang terdapat pada papan permainan (beberan). c) Anak belajar melalui bahasa.

Dengan permainan ular tangga ini, anak dapat mengembangkan kosa kata dan kemampuan berbahasa secara langsung. d) Anak belajar dengan bergerak.

Dengan media permainan ular tangga ini, anak dapat bergerak dengan menjalankan bidaknya atau bidar pada papan permainan.

Menurut Sadiman (2008), ada beberapa kelebihan media permainan yaitu: menyenangkan, memungkinkan adanya partisipasi untuk belajar, memberikan umpan balik, memungkinkan anak untuk memecahkan masalah-masalah, memberikan pengalamanpengalaman nyata,serta membantu meningkatkan kemampuan komunikatifnya.

2) Perbedaan Pengetahuan PHBS pada Kelompok Perlakuan 2.

Distribusi skor pengetahuan PHBS pada kelompok perlakuan 2 dapat digambarkan pada tabel berikut. Tabel 4.9 Distribusi Skor Pengetahuan PHBS pada Kelompok Perlakuan 2.

\begin{tabular}{cccc}
\hline Responden & Skor Pretest & Skor Posttest & Selisih \\
\hline 1 & 33 & 36 & 3 \\
2 & 33 & 37 & 4 \\
3 & 39 & 38 & -1 \\
4 & 36 & 34 & -2 \\
5 & 36 & 33 & -3 \\
6 & 39 & 36 & -3 \\
7 & 35 & 36 & 1 \\
8 & 36 & 36 & 0 \\
9 & 30 & 34 & 4 \\
10 & 35 & 33 & -2 \\
11 & 38 & 39 & 1 \\
12 & 38 & 39 & 1 \\
13 & 35 & 33 & 2 \\
14 & 34 & 35 & 1 \\
15 & 39 & 36 & 3 \\
16 & 42 & 35 & -7 \\
17 & 40 & 40 & 0 \\
18 & 30 & 31 & 1 \\
19 & 33 & 33 & 0 \\
20 & 35 & 35 & 0 \\
Mean & 35,8 & 35,4 & -7 \\
Maksimum & 30 & 40 & 45 \\
Minimum & 42 & 31 & 0 \\
\hline & & & 0 \\
\hline
\end{tabular}

Pada tabel 4.9 dapat diketahui bahwa terjadi penurunan rata-rata (mean) skor pengetahuan sebelum dan sesudah diberi penyuluhan dengan ceramah. Penurunan pengetahuan dapat dilihat dari rata-rata skor pretest dan posttest sebesar 35,8 menurun menjadi 35,4 pada rata-rata skor posttest. Selisih penurunan skor pengetahuan PHBS paling tinggi sebesar -7 dan paling rendah 4 , sedangkan rata-rata selisih Skorpretest dan posttest sebesar 0,15. Berdasarkan hasil analisis uji $\mathrm{t}$ berpasangan antara pretest dan posttest kelompok perlakuan 2 diperoleh skor $\mathrm{p}$ $=0,513>0,005$. Hal ini menunjukkan bahwa tidak terdapat perbedaan yang bermakna antara skor pretest dan posttest pada kelompok perlakuan 2 . 
Peneliti berasumsi bahwa kemungkinan hal ini disebabkan oleh beberapa faktor, yaitu faktor peneliti, faktor responden dan faktor media pembelajaran Ditinjau dari faktor peneliti yaitu peneliti belum mampu mengontrol suasana dan keadaan proses penelitian secara maksimal, sehingga terdapat beberapa responden yang kurang memperhatikan informasi yang disampaikan oleh peneliti.

Pada faktor responden, menurut Muhibin Syah dalam buku Psikologi Belajar, salah satu faktor yang paling penting mempengaruhi belajar yaitu faktor internal (faktor dari dalam siswa) meliputi keadaan atau kondisi biologis (jasmani) dan faktor psikologis (rohani) siswa. Keadaan jasmani siswa yang tidak baik seperti keletihan indra, keletihan fisik dan keletihan mental merupakan salah satu faktor penyebab kejenuhan dalam belajar. Kejenuhan dalam belajar adalah rentang waktu tertentu yang digunakan untuk belajar, tetapi tidak mendatangkan hasil. Faktor psikologis merupakan hal yang berpengaruh terhadap keberhasilan pemahaman seseorang meliputi segala yang berkaitan dengan mental dan meliputi 3 hal, yaitu intelegensi, kemauan, dan daya ingat. Selang jarak waktu posttest, perlakuan dengan ceramah, dan pretest yang mencapai satu minggu merupakan salah satu faktor penurunan daya ingat. Menurut pendapat Winkel (1999) dalam (Kuswana;2011), bahwa pada umumnya orang setelah belajar pertama kali, lupa dengan cepat, tetapi kemudian tidak begitu cepat. Gejala ini berkaitan dengan apa yang dikenal sebagai "Kurva Lupa Ebbinghaus", yaitu pada permulaan, retensi berkurang dengan cepat, tetapi kemudian pengurangan itu berangsur-angsur mengecil.

Intensitas perhatian responden atau kemauan responden untuk mendengarkan informasi yang disampaikan oleh peneliti juga menjadi salah satu faktor yang berperan penting dalam perubahan pengetahuan responden. Kurangnya intensitas perhatian responden menyebabkan tidak adanya perubahan pengetahuan responden ataupun berkurangnya pengetahuan responden walaupun telah mengikuti pendidikan kesehatan.

Keberhasilan suatu pendidikan kesehatan dipengaruhi oleh beberapa faktor. Salah satu faktor yang dapat dilihat dari hasil penelitian ini yaitu media yang digunakan. Pada kelompok perlakuan 2, pendidikan kesehatan yang diberikan yaitu dengan ceramah. ceramah adalah suatu cara dalam menerangkan dan menjelaskan ide pengertian atau pesan secara lisan kepada sekelompok sasaran sehingga memperoleh informasi tentang kesehatan. Penyuluhan metode ceramah merupakan metode yang paling sering digunakan untuk memberikan penyuluhan, tetapi metode ini biasanya kurang menarik bagi responden karena hanya mendengarkan dan orang berbicara sehingga terkesan membosankan. Kelemahan metode ceramah ini salah satunya juga menyebabkan pesan tidak tersampaikan dengan maksimal karena pendengar merasa bosan dan kadang kurang memperhatikan (Hasibuan,2009).

Kelemahan metode ceramah yang lain yaitu membuat peserta didik pasif, mengandung unsur paksaan kepada peserta didik, mengandung sedikit daya kritis peserta didik, bagi peserta didik dengan tipe belajar visual akan lebih sulit menerima pelajaran dibandingkan dengan peserta didik yang memiliki tipe belajar audio, sukar mengendalikan sejauh mana pemahaman belajar peserta didik, kegiatan pengajaran menjadi verbalisme dan jika terlalu lama dapat membuat jenuh (Simamora,2009)

3) Perbedaan Pengetahuan Posttest Antara Kelompok Perlakuan 1 dan Perlakuan 2.

Berdasarkan hasil analisis uji t-test tidak berpasangan antara posttest kelompok perlakuan 1 dan perlakuan 2 diperoleh Skor $\mathrm{p}$ $0,000<0,005$. Hal ini berarti terdapat perbedaan yang signifikan pada pengetahuan siswa tentang PHBS di sekolah dengan media ular tangga.

Berdasarkan hasil analisis uji t-test tidak berpasangan antara posttest kelompok perlakuan 1 dan perlakuan 2 diperoleh skor $\mathrm{p}$ $(0,000)$ lebih kecil dari 0,005, maka diperoleh hasil bahwa hasil hipotesis (Ho) ditolak dan hipotesis alternatif (Ha) diterima. Artinya bahwa terdapat perbedaan yang bermakna antara skor posttest pada kelompok yang mendapat perlakuan dengan media permainan ular tangga dengan kelompok yang mendapat perlakuan atau intervensi berupa ceramah.

Proses pendidikan disamping dipengaruhi oleh peserta didik, dipengaruhi pula oleh metode materi atau pesannya, pendidik atau petugas yang melakukannya, dan alat-alat bantu/ alat peraga pendidikan (Munadi,2010). Agar tercapainya suatu hasil yang optimal maka faktor-faktor tersebut harus bekerjsama secara harmonis (Hamalik,2008). Maulana (2009) menyebutkan bahwa keberhasilan pendidikan kesehatan dalam merubah perilaku dipengaruhi pula oleh penangkapan panca indera. Panca indra yang paling banyak menyalurkan pengetahuan ke otak adalah mata (kurang lebih $75 \%$ sampai $87 \%$ ), sedangkan $13 \%$ sampai $25 \%$ 
pengetahuan diperoleh atau disalurkan melalui indera yang lain.

Sejalan dengan kenyataan tersebut, Dale (1969) dalam Kuswana (2013) menyatakan bahwa semakin banyak indera yang digunakan untuk menerima sesuatu, maka semakin banyak dan semakin jelas pula pengertian/ pengetahuan yang diperoleh. Usman (2005) mengatakan penggunaan alat peraga yang relevan dengan tujuan pengajaran dapat meningkatkan hasil belajar sehingga lebih bermakna dan tahan lama.

Media adalah alat yang mempunyai fungsi menyampaikan pesan. Media sebagai alat pembelajaran mempunyai syarat antara lain, 1) harus bisa meningkatkan motivasi subyek untuk belajar, 2) merangsang pembelajaran mengingat apa yang sudah dipelajari, 3) mengaktifkan subyek belajar dalam memberikan tanggapan/umpan balik, 4) mendorong pembelajar untuk melakukan praktek-praktek yang benar (Septiana, 2014).

Ceramah adalah suatu cara dalam menerangkan dan menjelaskan ide pengertian atau pesan secara lisan kepada sekelompok sasaran sehingga memperoleh informasi tentang kesehatan. Penyuluhan metode ceramah merupakan metode yang paling sering digunakan untuk memberikan penyuluhan, tetapi metode ini biasanya kurang menarik bagi responden karena hanya mendengarkan dan orang berbicara sehingga terkesan membosankan. Kelemahan metode ceramah ini salah satunya juga menyebabkan pesan tidak tersampaikan dengan maksimal karena pendengar merasa bosan dan kadang kurang memperhatikan (Hasibuan,2009)Penelitian Apsiyah (2008) menghasilkan 40\% peserta didik merasa jenuh dan $20 \%$ merasa sangat jenuh dengan penerapan metode ceramah. Penelitian Pramiputra (2014) hasilnya peningkatan rata-rata skor pengetahuan setelah pendidikan kesehatan metode ceramah hanya meningkat dari 12,30 menjadi 14,27 sedangkan dengan metode visual leaflet meningkat dari 12,80 menjadi 18,07. Hal tersebut menunjukkan metode ceramah mulai tidak efektif dalam pemberian pendidikan kesehatan.

Sesuai dengan teori yang menyatakan bahwa penggunaan jenis media yang tepat akan memudahkan untuk mencapai tujuan pendidikan kesehatan yang dilakukan. Media pendidikan mempunyai beberapa manfaat antara lain menimbulkan minat bagi sasaran, dapat menghindari kejenuhan dan kebosanan, membantu mengatasi banyak hambatan dalam pemahaman, memudahkan penyampaian informasi, dan memudahkan penerimaan informasi bagi sasaran didik (Taufik, 2007). Menurut Suyanto $(2009 ; 2)$ salah satu alasan belajar menggunakan media permainan yaitu karena anak dapat belajar melalui panca indera. Dalam media permainan ular tangga ini, anak dapat belajar melalui penglihatan, pendengaran dan perabaan. Indera penglihatan yaitu dengan gambar-gambar tentang PHBS di sekolah yang terdapat di media permainan ular tangga, indera pendengaran yaitu ketika lawan main membacakan jawaban dengan menggunakan kartu jawaban atas pertanyaan yang terdapat pada papan permainan(jawa:beberan), serta indera perabaan saat pemain memindahkan bidak dari setiap kotak yang ada pada papan permainan (jawa:beberan).

Media permianan ular tangga dapat digunakan dalam pendidikan kesehatan untuk meningkatkan pengetahuan siswa tentang PHBS. Model permianan ular tangga ini pada dasarnya sama dengan bentuk permainan ular tangga biasa yaitu untuk menguasai. Menguasai pada permainan ular tangga. Kelebihan permainan ular tangga sebagai media pendidikan kesehatan yaitu terdapat pengetahuan tentang PHBS di Sekolah melalui gambar pada papan (jawa:beberan) maupun pertanyaan pada kotak dipapan (jawa:beberan) dan jawaban pada kartu jawaban serta adanya arti atau makna pada media permainan ular tangga di penelitian ini, contohnya pada gambar tangga maka adanya perilaku atau kejadian negatif berubah menjadi perilaku atau kejadian postif, misalnya apabila tidak ingin menderita sakit perut maka harus cuci tangan,begitu pula arti atau makna sebaliknya dengan gambar ular.

\section{Kesimpulan.}

Berdasarkan hasil penelitian dapat disimpulkan bahwa :

a. Terdapat peningakatan pengetahuan siswa tentang PHBS sebelum dan sesudah pendidikan kesehatan dengan media permainan ular tangga.

b. Terdapat penurunan pengetahuan siswa tentang PHBS sebelum dan sesudah pendidikan kesehatan dengan ceramah.

c. Terdapat pengaruh pendidikan kesehatan tentang PHBS dengan media permainan ular tangga, namun tidak terdapat pengaruh pendidikan kesehatan tentang PHBS dengan ceramah.

\section{Ucapan Terima Kasih}

Peneliti mengucapkan banyak terima kasih kepada pihak SDN 1 Limpakuwus dan SDN 2 Limpakuwus yang telah memberikan ijin penelitian di kelas IV serta seluruh pihak yang telah membantu terselesaikannya penelitian ini. 


\section{Daftar Pustaka}

Amir, M. Taufik, 2007, Inovasi Pendidikan Melalui Problem Based Learning, Jakarta: Kencana.

Andang, Ismail, 2009. Education Games Panduan Praktis Permainan yang menjadi Anak Anda Cerdas, Kreatif dan shaleh.Yogyakarta: Proumedia.

Apsiyah, 2008, Pengaruh Metode Ceramah terhadap Motivasi Belajar Pendidikan Agama Islam pada Siswa SMA N 1 Keronjo, Skripsi: Universitas Islam Negeri Syarif Hidayatullah Jakarta.

Charina Amelia, 2010, Efektivitas Permainan Ular Tangga untuk Meningkatkan Pengetahuan Tentang Bahaya Rokok Siswa Kelas VII SMP Ma'arif NU Tegal Tahun 2010, Skripsi: Universitas Negeri Semarang.

Depkes, 2010. Laporan Riskesdas. Jakarta : Dirjend Kesehatan RI.

Dwi Arifiani Nur Khamidah, 2011, Perbedaan Peningkatan Pengetahuan Tentang Perilaku Hidup Bersih dan Sehat (PHBS) antara Metode Permainan Monopoli dan Ceramah pada siswa SDN Kebandingan Kecamatan Kebandingan Kabupaten Tegal Tahun Ajaran 2010/2011, Skripsi: Universitas Negeri Semarang.

Hamalik, 2008, Psikologi Belajar dan Mengajar, Bandung: Sinar Baru

Rahmawati,Indah, 2009, Media Permainan Meningkatkan Motivasi Belajar Siswa, at https://suaraguru.wordpress.com/2009/02/09/m edia-permainan-meningkatkan-motivasibelajar-siswa/

Iqbal Mubarak W dkk, 2007. Promosi Kesehatan Sebuah Pengantar Proses Belajar Mengajar dalam Pendidikan. Yogyakarta : Graha Ilmu.

Kemenkes. 2014. Riset Kesehatan Dasar Tahun 2013. Jakarta: Kementrian Kesehatan Republik Indonesia

Kuswana, WS, 2011, Taksonomi Berpikir, Bandung: PT. Remaja Rosdakarya

Lucky Dwi Umiziah, 2016, Pengaruh Pendidikan Kesehatan terhadap Pengetahuan dan Sikap Tentang Perilaku Hidup Bersih dan Sehat (PHBS) pada Siswa SMP Muhammadiyah 1 Kartasura, Skripsi: Universitas Muhammadiyah Surakarta.

Machfoedz I dan Suryani E. 2009. Pendidikan Kesehatan Bagian dari Promosi Kesehatan. Yogyakarta : Fitramaya.

Muhammad Zamzami, 2014, Pengaruh Pendidikan Kesehatan dengan Metode Ular Tangga tentang Pencegahan Penyakit Pes terhadap Tingkat Pengetahuan dan Sikap Siswa SD Negeri 1 Selo Boyolali, Skripsi : Universitas Muhammadiyah Surakarta.

Maulana, 2009, Manajemen Sumber daya manusia, Jakarta:Salemba Empat

Munadi,Y. 2010. Media Pembelajaran. Jakarta:Gaung Persada Press
Notoatmodjo, S, 2010. Promosi Kesehatan Teori dan Aplikasi Edisi Revisi. Jakarta: Rineka Cipta.

Notoatmodjo S dkk, 2012. Promosi Kesehatan di Sekolah. Jakarta: Rineka Cipta.

Nur Annisa Alviana Dewi, 2015, Pengaruh Pendidikan Kesehatan tentang Perilaku Hidup Bersih dan Sehat (PHBS) dengan Metode Ceramah terhadap Pengetahuan dan Sikap pada Anak Panti Asuhan Keluarga Yatim Piatu Muhammadiyah Surakarta, Skripsi: Universitas Muhammadiyah Surakarta.

Pramiputra, 2014, Efektifitas Pendidikan Kesehatan Menggunakan Metode Ceramah dengan Leaflet terhadap Peningkatan Pengetahuan Pencegahan Demam Berdarah Dengue Di Desa Wonorejo Polokarto. Skripsi: Universitas Muhammadiyah Surakarta

Roestiyah N, 2012. Strategi Belajar Mengajar. Jakarta:Rineka Cipta

Sadiman, Arief, 2008. Media Pendidikan Pengertian, Pengembangan dan Pemanfaatannya.Jakarta: PT RajaGrafindo Persada.

Septiana, 2014, Pengaruh Pendidikan Kesehatan terhadap Tingkat Pengetahuan Remaja tentang Kesehatan Reproduksi di SMP Islam Rumah Ciputat, Jakarta,Skripsi: Universitas Islam Negeri Syarif Hidayatullah.

Simamora, H, Raymond, 2009, Buku Ajar Pendidikan dalam Keperawatan, Jakarta: Buku Kedokteran EGC

Siti Fatimah, 2012, Pengaruh Intervensi Promosi Kesehatan terhadap Pengetahuan, Sikap dan Praktek Perilaku Hidup Bersih dan Sehat Siswa Kelas 4 dan 5 SDN Kembaran Kecamatan Loano Kabupaten Purworejo Propinsi Jawa Tengah Tahun 2012, Skripsi: Universitas Indonesia.

Suyatno, 2009, Menjelajah Pembelajaran Inofatif. Sidoarjo: Masmedia Buana Pustaka

Syah, Muhibin, .2009, Psikologi Pendidikan dengan Pendekatan Baru, Bandung: PT Remaja Rosdakarya

Usman,Moh, Uzer. 2005, Menjadi Guru Profesional. Bandung:Remaja Rosdakarya.

Zulkifli,L., 2006, Psikologi Perkembangan, Bandung: Rineka Cipta 